\title{
ELECTRONIC MODE OF THE MODERN ADMINISTRATIVE DISCOURSE
}

\author{
Oksana A. Evtushenko \\ Volgograd State Technical University, Volgograd, Russia \\ Svetlana V. Pervukhina \\ Don State Technical University, Rostov-on-Don, Russia
}

\begin{abstract}
The study has been carried out in line with the current problems of modern discourse and genre studies related to the study of the evolution of administrative discourse, which is understood as a hybrid of oral and written communication. The article presents the results of the analysis of the Internet influence on the longestablished genres of administrative discourse. The concept of administrative Internet communication has been clarified. The study of administrative discourse in the Internet space clearly demonstrates that even the most conservative sphere of activity is influenced by modern technologies and extralinguistic factors have the most direct impact on the genres formation. The administrative Internet functions are singled out: informing, requesting information, initiating discussions, organization. The genres of administrative Internet communication are analyzed, in the modern administrative discourse we have identified the most indicative in terms of management hypergenres and genres: the hypergenre "corporate web portal" or "Intranet", the genre "email", the genre "online meeting" or "video conferencing", the genre "electronic documents". This article details two genres: "corporate web portal" and "online meeting". The conducted survey made it possible to determine the pragmatic nature of the considered corporate web portal hyper-genre - keeping to corporate culture, interactivity, speed. It has been established that due to the mentioned Internet genres emergence, a partial decrease in distance and erasing of the status line in the "head-subordinate" pair occurs. It is concluded that cyberspace is transforming the power-subordinate nature of administrative communication into democratic partnership, as well as there is the transformation of traditional genres with the advent of electronic communication in the field of management. It is concluded that the theory of speech genres is applicable to study of the evolution of administrative communication, and new techniques are required to take into account linguistic changes caused by the development of information technologies.
\end{abstract}

Key words: electronic mode, administrative Internet communication, Internet genre, hypergenre, corporate web portal, online meeting, conference call.

Citation. Evtushenko O.A., Pervukhina S.V. Electronic Mode of the Modern Administrative Discourse. Vestnik Volgogradskogo gosudarstvennogo universiteta. Seriya 2. Yazykoznanie [Science Journal of Volgograd State University. Linguistics], 2020, vol. 19, no. 5, pp. 99-109. (in Russian). DOI: https://doi.org/10.15688/jvolsu2.2020.5.9

\section{ЭЛЕКТРОННЫЙ МОДУС СОВРЕМЕННОГО АДМИНИСТРАТИВНОГО ДИСКУРСА}

\author{
Оксана Александровна Евтушенко \\ Волгоградский государственный технический университет, г. Волгоград, Россия \\ Светлана Владимировна Первухина \\ Донской государственный технический университет, г. Ростов-на-Дону, Россия
}

Аннотация. Исследование выполнено в русле актуальных проблем современной дискурсологии и жанроведения, связанных с изучением эволюции административного дискурса, который понимается как гибрид 


\section{РАЗВИТИЕ И ФУНКЦИОНИРОВАНИЕ РУССКОГО ЯЗЫКА}

устной и письменной коммуникации. В статье представлены результаты анализа влияния Интернета на административный дискурс, которое выразилось в трансформации уже сложившихся жанров и формировании новых. Уточнено понятие административной интернет-коммуникации. Выделены функции административного Интернета: информирование, запрос информации, инициация обсуждений, организация управления, реклама. Описаны жанры административной интернет-коммуникации и подробно охарактеризованы востребованные в современном административном дискурсе информационные жанр и гипержанр (корпоративный интернет-сайт и корпоративный веб-портал, или интранет) и интерактивные жанры (селекторное совещание и онлайн-совещание). Определены их прагматические свойства - корпоративность, интерактивность, быстрота. Показано, как с появлением электронной коммуникации в сфере управления происходит изменение традиционных жанров. Установлено, что интернет-жанры способствуют уменьшению статусной дистанции между руководителем и подчиненным, что киберпространство трансформирует властноподчинительный характер административной коммуникации в демократически-партнерский. Сделан вывод о том, что для изучения эволюции административной коммуникации применима теория речевых жанров и требуются новые методики, позволяющие учитывать лингвистические изменения, обусловленные развитием информационных технологий.

Ключевые слова: административный дискурс, административная интернет-коммуникация, интернетжанр, гипержанр, корпоративный веб-портал, онлайн-совещание, селекторное совещание.

Цитирование. Евтушенко О. А., Первухина С. В. Электронный модус современного административного дискурса // Вестник Волгоградского государственного университета. Серия 2, Языкознание. - 2020. - Т. 19, № 5. - C. 99-109. - DOI: https://doi.org/10.15688/jvolsu2.2020.5.9

\section{Введение}

Развитие информационных технологий послужило мощным толчком к формированию нового пространства - электронного, в рамках которого обеспечивается передача и хранение различной информации, а также обмен управленческими решениями.

В современном социуме ни одна область социальной деятельности не обходится без обращения к разнообразным документам, что делает современную цивилизацию полностью зависимой от документации. Сейчас общество переживает период перехода от «бумажной» к электронно-мультимедийной коммуникации. По мнению В.С. Соколова, в связи с тем, что у каждого типа общения имеются свои ограничения и преимущества, вскоре будет возможна комбинация всех типов социальной коммуникации (устной, документной, электронной) [Соколов, 2005, с. 10].

В целом ряде работ описывается лингвистика Интернета, то есть его языковые и коммуникативные особенности [Асмус, 2005; Войскунский, 2001; Галичкина, 2001; Горошко, 2010; Зуляр, 2006; Иванов, 2000; Смирнов, 2004; Соколов, 2005; Crystal, 2004; Herring, 1996; Thurlow, 2001; и др.]. В этих публикациях электронная коммуникация определяется как современная форма особого типа социального общения при замещении устной и письменной формы электронной. Являясь прогрессивным и перспективным, рассматриваемый тип коммуникации последовательно развивается.

Информационные технологии оказывают непосредственное воздействие на административную сферу. Возникают такие термины, как «синхронизация электронных систем», «электронный архив организационно-распорядительной документации», «электронный отчет», «электронная подпись», «электронный протокол заседаний», «электронный документооборот», «электронный язык руководителя», «электронная деловая переписка», «онлайнголосование». Административная коммуникация в сети Интернет направлена на информирование, запрос информации, инициацию обсуждений, организацию управления, рекламу, реализуя, таким образом, универсальные функции: информирующую, организующую, координирующую и контролирующую. В административной традиционной или интернеткоммуникации они являются первостепенными, так как суть управленческой деятельности сводится к постоянной координации работы департаментов организации и ее отдельных представителей для достижения общих целей.

Исследование, результаты которого представлены в статье, ориентировано на определение направления эволюции административного дискурса посредством описания жанров 
электронного модуса современного административного дискурса.

\section{Материал и методы исследования}

В работе использовались следующие методы исследования: понятийное моделирование, интерпретативный анализ, внешнее анкетирование и опрос информантов, интроспекция.

Под интернет-жанром, вслед за Е.И. Горошко и Т.Л. Поляковой, понимаем «устойчивые типы текста, назначение которых определяет его форму и которые обслуживают типическую ситуацию коммуникации в сети Интернет» [Горошко, Полякова, 2015, с. 119]. Наличие большого количества классификаций интернет-жанров на основе различных критериев привело к трудностям их вычленения в виртуальном пространстве. Мы руководствовались комплексной моделью интернетжанра, предложенной Л.Ю. Щипициной и предполагающей учет следующих его параметров: 1) медийных - синхронность, интерактивность, оформление жанра; 2) прагматических хронотоп, коммуникативная цель; 3 ) структурносемантических - структурные элементы; 4) языковых - языковые средства, специфические для этого жанра [Щипицина, 2009, c. 155-158]. Данная модель послужила базой для комплексного описания информационных жанров в нашей работе.

Система жанров в интернет-коммуникации многослойна и включает гипержанры, жанры и субжанры. Гипержанр объединяет в себе несколько жанров, в то время как субжанр - это минимальная единица [Дементьев, Седов, 1998; Кожевникова, 1979]. Согласно классификации Е.И. Горошко и Е.А. Жигалиной, к гипержанрам относятся: социальная сеть, электронная библиотека, блог, сайт [Горошко, Жигалина, 2010]. Можно предположить, что гипержанром является и «корпоративный веб-портал». Широкий репертуар жанров данного гипержанра формируют: объявление, информационное сообщение, деловое письмо, инструкция, распоряжение, приказ, видеосовещание, онлайн-собрание, блог руководителя, в том числе комментарии, и др.

Мы учитывали также классификации жанров административной интернет-коммуникации в зависимости от их функции, в частности классификацию О.Н. Морозовой, которая выделяет информационные жанры (корпоративные сайты, административные документы, объявления, законодательные сайты, интранет) и интерактивные жанры (имейл, видеоконференция, онлайн-совещания или заседания) [Морозова, 2011, с. 158]. Наши наблюдения показывают, что наиболее востребованными в административной интернет-коммуникации являются информационные жанры «корпоративный интернетсайт», «интранет» и интерактивный жанр «онлайн-совещание».

В качестве материала исследования использован корпус текстов, составленный в результате сплошной выборки из опубликованных материалов деловой коммуникации, включая тексты, размещенные в сети Интернет, из картотеки записей устной и письменной речи, а также из внешних опросов информантов, осуществленных интранет-порталом inside-pr.ru и порталом www.rbc.ru. Единицей исследования является текстовый фрагмент, в котором выражены конститутивные признаки институциональных административных отношений между участниками коммуникации.

\section{Результаты и обсуждение}

\section{Информационные жсанры}

Корпоративные интернет-сайты тип публичного внешнего и внутреннего общения субъектов управления. О.Н. Морозова выделяет следующие его преимущества: 1) размещение большого количества материала без временных и пространственных ограничений; 2) экономию усилий и времени при доставке информации, обновляемой в любой момент; 3) создание и поддержание имиджа организации; 4) оперативную взаимосвязь со своими подчиненными или вышестоящими органами управления [Морозова, 2011, с. 158-160].

В сфере административного общения появляется новый интернет-гипержанр - корпоративный вебпортал, или интранет. С технической точки зрения интранет - это «распределенная корпоративная сеть, предназначенная для обеспечения доступа сотрудников к корпоративным информационным ресурсам и использующая программные продук- 
ты и технологии Интернет. Интранет позволяет контролировать доступ к корпоративной информации» (Интранет). По определению, представленному в словаре «Cambridge Advanced Learner's Dictionary \&Thesaurus», Intranet - «a system of connected computers which works like the internet, and which allows people within an organization to communicate with each other and share information» - система объединенных компьютеров, работающая как Интернет, позволяет сотрудникам организации общаться и делиться информацией (перевод наш. - O. E., C. П.). Таким образом, учитывая английское происхождение слова интранет, мы может заявить об ориентированности данного технического достижения на коммуникацию. Обращаясь к медийным параметрам данного гипержанра, Л.Ю. Щипицина отмечает, что оформление веб-портала представляет собой интернет-платформу, которая объединяет множество программных элементов (HTTP Wеbинтранет сервер, SMTP/IMAP e-mail почтовый сервер, сервер обмена сообщениями (MSN Messenger, Jabber), NNTP cepвер новостей, VoIP сервер внутрикорпоративной телефонии) [Щипицина, 2009]. Это тип асинхронной коммуникации, то есть не требующей мгновенного ответа адресата, происходящей в веб-пространстве при неограниченном доступе к электронному контенту и имеющей публичную одно- или двунаправленность. Элементы программного обеспечения являются ключевыми факторами при создании текстов конкретного жанра. Например, при составлении текста документа автор использует имеющийся шаблон, предлагаемый программой, таким образом, элементы программного обеспечения всегда связаны с создаваемым текстом. Разделяя мнение О.Ю. Усачевой и Л.Ф. Компанцевой о том, что интранет, или корпоративный веб-портал, - это техническая платформа или формат для решения минимальных коммуникативных задач руководителем и подчиненным [Усачева, 2010], мы одновременно соглашаемся с М.А. Ульяновой в том, что термин «формат» не имеет прямого отношения к образованию дискурса и не влияет на протекание коммуникативных интеракций и, соответственно, «корпоративный веб-портал» имеет право на существование как административный интернет-гипержанр [Ульянова, 2014].
Корпоративный веб-портал-многоуровневый, многофункциональный интернет-гипержанр административного дискурса, обеспечивающий институциональную коммуникацию статусно-неравноправных участников, относящихся к одной организации и общающихся на заданную тему относительно функционирования данной организации, в которой культивируются корпоративные ценности и традиции, ставятся задачи, отдаются приказы, распоряжения и пр.

Л.Н. Кольцова выделяет базовые функции данного интернет-гипержанра: коммуникативную (виртуальные конференции, совещания и голосования); информационную (передача, хранение, поиск данных, обмен информацией, создание отчетов, рассылка приказов всем сотрудникам); контролирующую (увеличение скорости обмена информацией, принятие решений, реагирование на ситуацию, проведение опросов, рейтинговых голосований среди сотрудников компании, формирование архива опросов) [Кольцова, 2010].

Корпоративный веб-портал - это, прежде всего, административный инструмент для руководителя, значительно упрощающий его работу в силу объединения всех элементов корпоративной коммуникации. Коммуникативные потоки на веб-портале делятся на вертикальные и горизонтальные. К вертикальным относим те, что инициированы руководителем: издание приказов, распоряжений, внутренних инструкций, формулирование задач, информирование, оповещение о необходимости действий, контроль версий документов, запрос отчетов, управление или сопровождение выполнения заданий, управление знаниями сотрудников, делегирование полномочий и пр. Горизонтальные потоки коммуникации инициированы сотрудниками организации для внутреннего корпоративного общения: форумы, страницы поздравлений, созданные сотрудниками e-learning курсы, записи проведенных вебинаров.

Важной особенностью данного интернетгипержанра является уменьшение дистанции, частичное стирание статусной грани в коммуникации «руководитель - подчиненный». Интернет-пространство смягчает строгость, официальность и властно-подчинительный характер административной коммуникации. 
Подчиненный может обратиться к любому руководителю из всей иерархии руководящего звена, что в ситуации реального общения весьма затруднительно.

Интернет-гипержанр «корпоративный веб-портал» имеет сложную структуру, подчиненную основным целям данного административного жанра - управлению, интеграции, размещению, хранению, передаче информации. Приведем пример структурных элементов портала Rambler\&Co: Главная, Лента новостей, Поиск коллег, Совещания и встречи, Рабочий прочесс, Электронные услуги и бонусы для сотрудников, Библиотека, Анонимный чат с руководством, Заявления на отпуск, Увольнения, Кадровые заявки, Единая база кандидатов, Оиенка 360, Мероприятия, статистика посещения, Постановка КПЕ, Список проектов, Статистика. Анализ структуры различных интранет-порталов (inside-pr.ru, www.rbc.ru, ramblergroup.com) показал, что составляющие ее единицы могут меняться в зависимости от целей конкретной организации, но контент сводится к следующим темам: документная, корпоративная, административная коммуникация.

Изучение результатов интернет-опроса топ-руководителей об эффективности интранета для ведения дел, осуществленного интранет-порталом inside-pr.ru и опубликованного в статье «Интранет: основные задачи и эффективные решения», размещенной на нем, позволило нам выявить прагматические свойства данного интернет-жанра. Он направлен на:

1) объединение и сплочение коллектива:

...Для успеха требуется сплочение команды, превращение работников в единомышленников. Поздравления с днем рождения, появлением на свет ребенка, окончанием испытательного срока и прочим, фотографии с корпоративных мероприятий, новости, планы компании - все это позволяет лучше сплотить коллектив (особенно если он рассредоточен по офисам) и сделать бизнес более «человечным», «живым» (Н. Ляховская, заместитель директора по маркетингу и рекламе кадрового агентства «Визави Консалт»);

2) воспитание и поддержание корпоративной культуры:

Эффективность использования внутреннего сайта как средства укрепления корпоративного духа компании, передачи информации от руководства к подчиненным, а также обратной связи сегодня вряд ли может подвергаться сомнению. Для сравнения можно рассмотреть пример печатной корпоративной газеты. Ее основные недостатки - сравнительно невысокая оперативность (Е. Ганьшина, директор по связям с общественностью «Евразийского банка развития»);

К идеологическим целям, безусловно, относятся задачи развития корпоративной культуры организации, пропаганда ее ценностей, вовлечение сотрудников во внутреннюю жизнь компании (В. Зинченко, вице-президент «Номос-Банка»);

Интранет как никакой другой инструмент дает возможность каждому сотруднику ежедневно испытывать чувство причастности к одной команде, к одному большому делу благодаря вовлеченности во внутрикорпоративное информационное поле. И если стратегия развития компании предполагает такую важную составляющую, как корпоративные коммуникации, то интранет будет лучшим способом поддержки и развития корпоративной культуры (Е. Харитонова, пресс-секретарь управляющей компании «Арбат Капитал»);

\section{3) интерактивность и легкодоступность:}

Основное назначение любого корпоративного портала - обеспечить удобный и оперативный доступ сотрудника к необходимым ему материалам, а также наладить эффективное общение среди работников (А. Набока, генеральный директор компании «Designonline»); каций:

4) продвижение корпоративных коммуни-

Цели, которые преследуют руководители, состоят в устранении внутренних информационных барьеров, обеспечении беспрепятственного и оперативного доступа к информации и повышении скорости и качества коммуникаций для решения любых вопросов - как производственных, так и социальных (А. Карпов, директор по персоналу «LG Electronics RUS»);

Преимуществ у интранета много, но главное из них - это качественно другой уровень внутренних коммуникаций, что, безусловно, сильно облегчает решение многих как ежедневных, так и стратегических задач. А если идти дальше, то уровень развития внутренних коммуникаций напрямую коррелируется с уровнем развития корпоративной культуры компании, отражает ее подлинные интересы и приоритеты» (Ю. Григорьян, директор по управлению персоналом УК «Альфа-Капитал»).

Данному гипержанру присуща мультимедийность в полном объеме: внутри «веб- 


\section{РАЗВИТИЕ И ФУНКЦИОНИРОВАНИЕ РУССКОГО ЯЗЫКА}

портала» находятся фотографии сотрудников организации, текстовые материалы совещаний, звуковые файлы, картинки. Интерактивность данного гипержанра обусловлена целью его создания - объединением членов всей организации. Таким образом, в речевой деятельности одновременно принимает участие не менее двух субъектов административной коммуникации.

Итак, гипержанр «корпоративный вебпортал» обладает всеми параметрами, присущими интернет-жанру: мультимедийными, прагматическими, структурно-семантическими и языковыми. Автором данного гипержанра выступает руководитель, который инициирует коммуникацию со своим адресатом (подчиненным) и направляет ему аккумулированную систематизированную информацию в общем интернет-пространстве.

В связи со строгой конфиденциальностью и обязательством неразглашения информации, содержащейся на корпоративном веб-портале, нам представляется затруднительным дать полное описание всех его составляющих, провести лингвистический анализ текстовых документов, изучить структурно-семантические и языковые параметры интернет-жанров, создающих гипержанр «корпоративный веб-портал».

\section{Интерактивные жанры}

Современные информационные технологии открывают руководителю такие перспективы, которые дают возможность работать оперативно, быть доступным для своих подчиненных, позволяют увеличивать объемы информации, требуемой для решения административных задач. Правильная организация коммуникации должна вовлекать всех сотрудников в процесс достижения целей компании. Рассматриваемые интернет-жанры реализуются в вербально-визуальном общении, предоставляющем возможность информировать сотрудников всех филиалов и удаленно обсуждать текущие вопросы.

Существует такой вид интерактивных жанров, как селекторные совещания. И.С. Шевченко рассматривает жанры «селекторное совещание» и «аудиоконференция» в рамках корпоративного дискурса с позиции теории Ю. Хабермаса. Ученый определяет эти жан- ры как речевые события с заданными ролями, стандартизованной ситуацией и сценарием, которые уже являются повседневной реальностью для многих организаций и все больше превращаются в необходимый инструмент оперативного управления, в удобное средство проведения виртуальных бизнес-встреч и совещаний [Шевченко, 2007, с. 13].

Согласно принципам критической теории стратегий и тактик, роли, социальный контекст находятся в прямой зависимости от внешних языковых и социокультурных факторов. В связи с этим образование данных жанров обусловлено совершенствованием функциональности оборудования, появлением новых технологий, интегрирующих с компьютерными приложениями.

В рамках этого жанра осуществляются все функции управления одновременно. Селекторное совещание - это жанр административного дискурса, в рамках которого разворачивается речевое событие во главе с руководителем и несколькими участниками, задача которых состоит в разработке плана, утверждении или согласовании действий. Подобные совещания носят формальный характер, так как их основными составляющими являются протоколы и отчеты, а быстрота принятия решений отличает селекторное совещание от традиционных видеоконференций.

Участники коммуникации в этих жанрах вступают в иерархическое административное общение, при котором исполнительность, системность и быстрота принятия решений реализуются на всех уровнях общения.

Рассмотрим пример селекторного совещания.

- Здравствуйте, уважаемые коллеги! Мы начинаем заседание рабочей группы правительственной комиссии в связи с чрезвычайной ситуацией, которая возникала на территории Московской области. В результате столкновения двух поездов: пассажирского и товарного, к сожалению, погибли и пострадали люди. Осуществляется полномасштабная спасательная операция, привлечены силы и средства МЧС России, Министерства внутренних дел, Минздрава, активно работает группировка сил Москвы и области... Яценко Виктор Николаевич, пожалуйста, доклад о состоянии на три часа дня.

- Уважаемый министр РФ, уважаемые коллеги, в половину первого в Нарофоминском райо- 
не в результате схода с рельсов вагонов произошло столкновение... В поезде находилось триста девяносто четыре пассажира. По предварительным данным в результате аварии пострадало пятьдесят человек... В короткие сроки создана система антикризисного управления, организована работа рабочей группы... обстановка находится на контроле, доклад закончен.

- Виктор Николаевич, продолжаем масштабное реагирование, организуйте устойчивую систему управления в зоне ЧС... Об обстановке, сложившейся в зоне ЧС, Швецов Юрий Анатольевич, руководитель спасательной службы, слушаем Вас.

- Здравия желаю, находясь на месте, восемнадцать человек госпитализированы, пять погибших, работает восемь единиц воздушной техники... Доклад закончен. зоне ЧС?

- Так, дополнительные силы требуются в

- Не требуются.

- Так, коллеги, работу продолжаем. Начальник управления авиацией, я попрошу организовать воздушный коридор... Это первое. Второе, доклады каждый час. Следующее, я попрошу, МВД у нас на связи? Вижу вас. Организуйте транспортные коридоры в зону ЧС, это первое, второе, организуйте объездные пути. Нужна будет дополнительная поддержка и инструкции, обращайтесь. МИД на связи у нас? Организуйте прямую линию с Кишиневом... Коллеги, реагирование продолжается. Есть какието общие вопросы у нас?

Некоторое молчание.

- Если вопросов нет, в четыре часа дня заседание рабочей группы, я убываю в зону ЧС (Селекторное совещание).

Данный текстовый фрагмент демонстрирует, как в ходе обсуждения одновременно решаются все административные задачи: контроль (заслушиваются отчеты руководителей подразделений о ходе работы); планирование (на основе чего ставятся новые цели); организация (обговариваются способы их достижения, назначаются ответственные и сроки выполнения); мотивация (предпринимаются попытки побудить работников к активным действиям). Все речевые и языковые средства строго подчинены коммуникативной цели селекторного совещания - быстрому получению текущей информации и ее оценке. Четкость, лаконичность речи участников совещания обеспечены использованием форм и конструкций страдательного залога, двусоставных предложений (Осуществляется полно- масштабная спасательная операчия; Привлечены силь и средства; Реагирование продолжается; Я убываю), числительных (находилось триста девяносто четыре пассажира, пострадало пятьдесят человек), вводных слов, определяющих последовательность действий (это первое, второе, следующее). Стремительность селекторного совещания вербализуется не только посредством эпитетов (активный, полномасштабнызй, короткий, устойчивыц̆), но и путем опускания некоторых членов предложения (nожалуйста, доклад о состоянии на 15:00), союзов (Нужна будет дополнительная поддержка и инструкиии, обращайтесь). Конструкции в страдательном залоге акцентируют внимание участников на выполненных действиях и поставленных задачах (создана сuстема, организована работа, 18 человек госпитализированы) и тем самым экономят время, отведенное на совещание. Техническая специфика проведения данного совещания предопределяет особенности коммуникации: проверка связи (МВД у нас на связи? Вижу вас, МИД на связи у нас?), акцентирование начала и окончания речи (доклад закончен). Речевые характеристики административного жанра селекторного совещания подчинены его техническим свойствам: онлайнформату, темпу его проведения, быстроте принятия решений.

Наряду с уже существующим жанром селекторного совещания, активно развивается еще один - онлайн-совещание. Это синхронный инструмент в виртуальном пространстве, где работники организации обсуждают управленческие вопросов. Данная форма коммуникации существует не так давно, не более 10 лет, и как самостоятельный интернет-жанр еще не была исследована. Размещенные на портале www.rbc.ru в статье «Хватит болтать: почему компании запрещают совещания» результаты анализа мнений руководителей разных уровней, представленного в глобальном исследовании, проведенном лондонской консалтинговой компанией «STL MicrosoftTraining» в 2017 г., показывают, что современные руководители видят пользу онлайн-совещаний и отдают им предпочтение по разным причинам:

1) лаконичность высказываний и их эмоционально-нейтральная окраска: 


\section{РАЗВИТИЕ И ФУНКЦИОНИРОВАНИЕ РУССКОГО ЯЗЫКА}

Текст - это принципиально другая коммуникация. Вживую люди могут выступать по 10 минут и не сказать вообще ничего. В тексте это сделать труднее, поэтому обсуждение становится более конкретным, предметным и качественным. Плюс оно почти лишено ненужных эмоций, которые часто возникают на деловых встречах (А. Козловский, руководитель отдела «Манго Телеком»);

2) эффективность коммуникаций:

Здесь нет варианта по пути за кофе заскочить к коллеге и поставить ему неожиданную задачку. И нет возможности забыть или потерять свою задачу: от всего остаются электронные следы» (М. Сундалов, руководитель онлайн-школы «Englishdom»);

3) активность коммуникаций:

В итоге это дает куда лучшие результаты: все задачи четко сформулированы, каждый комментирует по существу. В общем конференц-зале все молча сидели с блокнотами, а теперь со своих рабочих мест сотрудники активно обсуждают вопросы. Получается, что это удобнее и сотруднику, и руководителю (А. Банников, генеральный директор «Фотосклад.ру»);

4) экономичность коммуникаций:

Совещания были необходимы в доцифровую эпоху. С развитием интернета и систем по управлению проектами практика совещаний стала обременением для современного бизнеса, ведь любое совещание отнимает самое ценное - время (А. Першиков, директор фонда «KeyGroup»).

Онлайн-совещания - это гибрид устнописьменного синхронного полилога в виртуальном пространстве. Его участники играют различные коммуникативные роли, вступая в разнообразные речевые взаимодействия, имеют возможность прибегать к нескольким видам адресации. Полилоги административного дискурса моносемантичны, поскольку направлены на решение одной проблемы и имеют лингвистические и экстралингвистические особенности. О.Н. Дубровская предлагает говорить о трансформации речевого жанра, в котором цели и задачи интернет-общения остаются теми же, что и во время реального общения, основные особенности жанра - лингвистическое выражение и цель использования жанра - сохраняются [Дубровская]. Мы согласимся в этом с ученым, добавив, что языковые и речевые изменения обусловлены техническими инновациями.

\section{Заключение}

Административный дискурс в современном социолингвистическом пространстве, пересекаясь с особой сферой общения - интернет-коммуникацией, предоставляет большие коммуникативные возможности в сфере административного общения, будучи неким гибридом устной и письменной коммуникаций, позволяет расширить их возможности и объединить различные виды информации. Данное пересечение приводит к трансформации некоторых традиционных жанров в интернет-жанры. Для их изучения, с одной стороны, применима теория речевых жанров, с другой стороны, необходимы новые методики, учитывающие появление в административной коммуникации электронного посредника и происходящие в связи с этим лингвистические изменения.

Исследование административного дискурса в интернет-пространстве демонстрирует, что даже самая консервативная сфера деятельности подвержена влиянию современных технологий и экстралингвистические факторы оказывают прямое воздействие на образование жанров.

\section{СПИСОК ЛИТЕРАТУРЫ}

Асмус Н. Г., 2005. Лингвистические особенности виртуального коммуникативного пространства : дис. ... канд. филол. наук. Челябинск. $265 \mathrm{c}$.

Войскунский А. Е., 2001. Развитие речевого общения как результат применения Интернета. URL: http://www.psynet.by.ru/index.html (дата обращения: 02.09.2019).

Галичкина Е. Н., 2001. Специфика компьютерного дискурса на английском и русском языках : автореф. дис. ... канд. филол. наук. Астрахань. $18 \mathrm{c}$.

Горошко Е. И., 2010. Особенности создания текста ВЕБ-страницы // Материалы научно-практической конференции «Понимание в коммуникации». М. : МГГИИ. С. 26-27.

Горошко Е. И., Жигалина Е. А., 2010. Виртуальное жанроведение: устоявшееся и спорное // Вопросы психолингвистики. № 12. С. 105-124.

Горошко Е. И., Полякова Т. Л., 2015. К построению типологии жанров социальных медий // Жанры речи. № 12. С. 119-127. 
Дементьев В. В., Седов К. Ф., 1998. Социопрагматический аспект теории речевых жанров. Саратов : Изд-во Сарат. пед. ин-та. 107 с.

Дубровская О. Н. Речевые жанры, речевые события и новые средства коммуникации. URL: https:/ www.sgu.ru/archive/old.sgu.ru/files/ dubrovskaya_5.doc. (дата обращения: 25.08.2019).

Зуляр Ю. А., $200 \overline{6}$. Массовые коммуникации в рекламе. Иркутск : Оттиск. 405 с.

Иванов Л. Ю., 2000. Язык Интернета: заметки лингвиста // Словарь и культура русской речи. М. : Азбуковник. С. 35-45.

Кожевникова К. В., 1979. Об аспектах связности в тексте как целом // Синтаксис текста / отв. ред. Г. А. Золотова. М. : Наука. С. 49-67.

Кольцова Л. Н., 2010. Внутренний веб-портал // Секретарь-референт. № 10. С. 18-25.

Морозова О. Н., 2011. Политическая интернет-коммуникация: ее роль, функции и формы // Политическая лингвистика. № 1. С. 156-161.

Смирнов Ф. О., 2004. Национально-культурные особенности электронной коммуникации на английском и русском языках : дис. ... канд. филол. наук. Ярославль. 220 с.

Соколов В. С., 2005. Документационное обеспечение управления. М. : Форум-Инфра-М. 233 с.

Ульянова М. А., 2014. Классификация жанров интернет-дискурса // Linguamobilis. № 3. C. 102-110.

Усачева О. Ю., 2010. К определению понятия «жанр интернета» и построению модели жанра в среде интернет // Мир русского слова.№ 1. C. 51-57.

Шевченко И. С., 2007. Теория Юргена Хабермаса и критический анализ дискурса // Вестник ХНУ им. В.Н. Каразина. № 773. С. 12-15.

Щипицина Л. Ю., 2009. Жанры компьютерноопосредованной коммуникации. Архангельск : Помор. ун-т. 238 с.

Crystal D., 2004. The Language Revolution. Cambridge : Polity Press. $128 \mathrm{p}$.

Herring S., 1996. Two Variants of an Electronic Message Schema // Computer-Mediated Communication: Linguistic, Social and Cross-Cultural Perspectives. Amsterdam : Routledge. P. 13-28.

Thurlow C., 2001. The Internet and Language // Concise Encyclopedia of Sociolinguistics. [S. 1.] : Elsaivier. P. 105-125.

\section{ИСТОЧНИКИ}

Интранет: основные задачи и эффективные решения. URL : https://inside-pr.ru/zhurnal/portalyi-seti/intranet-portal/item/396-intranetosnovnye-zadachi-i-effektivnye-resheniya (дата обращения: 25.08.2019).
Интранет - Интранет // Словарь IT : Интернет. URL: http://edumarket.ru/glossary/internet/3301 (дата обращения: 30.08.2019).

Селекторное совещание - Селекторное совещание по столкновению поездов. URL: https:// www.m24.ru/videos/dtp/20052014/51167 (дата обращения: 20.08.2019).

Хватит болтать: почему компании запрещают совещания. URL: https:/www.rbc.ru/own business/ 17/01/2018/5a5c76e19a79472b3d4128b0 (дата обращения: 25.08.2019).

RamblerGroup. URL: https://ramblergroup.com/assets/ media/afishadaily (дата обращения: 23.08.2019).

\section{REFERENCES}

Asmus N.G., 2005. Lingvisticheskie osobennosti virtual'nogo kommunikativnogo prostranstva: dis. ... kand. filol. nauk [Lingiustic features of virtual space. Cand. philol. sci. diss.]. Cheljabinsk.26 p.

Vojskunskij A. E., 2001. Razvitie rechevogo obshhenija kak rezul'tat primenenija Interneta [Development of speech communication as the result of the Internet use]. URL: http:// www.psynet.by.ru/index.html.

Galichkina E. N., 2001. Specifika komp'juternogo diskursa na anglijskom i russkomjazykah: avtoref. dis. ... kand. filol. Nauk [The specifics of computer discourse in English and RussianCand. philol. sci. abs. diss.]. Astrahan'. 18 p.

Goroshko E. I., 2003.Osobennosti sozdanija teksta VEBstranicy [Features of creating web page text]. Materialy nauchno-prakticheskoj konferencii "Ponimanie v kommunikacii" [Materials of scientific conference "Understanding in communication»]. M. MGGII. pp. 26-27.

Goroshko E.I., Zhigalina E.A., 2010. Virtual'noe zhanrovedenie: ustojavsheesja i spornoe [Virtual genre studies: well established and controversial]. Voprosy psiholingvistiki [Issue of psycholinguistics], no.12, pp. 105-124.

Goroshko E.I., Poljakova T.L., 2015. K postroeniju tipologii zhanrov social'nyh medij [Towards a typology of social media genres]. Zhanry rechi [Speech Genres]. №12. pp.119-127.

Dement'ev V.V.,Sedov K.F., 1998. Sociopragmaticheskij aspekt teorii rechevyh zhanrov [Sociopragmatic aspect of the theory of speech genres]. Saratov. $107 \mathrm{p}$.

Dubrovskaja O.N. Rechevye zhanry, rechevye sobytija i novye sredstva kommunikacii [Speech genres, speech events and new means of communication]. URL: https://www.sgu.ru/archive/old.sgu.ru/files/ dubrovskaya_5.doc. 


\section{РАЗВИТИЕ И ФУНКЦИОНИРОВАНИЕ РУССКОГО ЯЗЫКА}

Zuljar Ju.A., 2006. Massovye kommunikacii v reklame: Uchebnik dlja vuzov [Mass Communications in Advertising: A Textbook for High Schools]. Irkutsk: Ottisk.405 p.

Ivanov L. Ju., 2000. Jazykinterneta: zametki lingvista [Internet language: notes of a linguist]. Slovar' $i$ kul 'tura russkoj rechi [Vocabulary and culture of the Russian speech]. M.: Azbukovnik. pp. 35-45.

Kozhevnikova K.V., 1979. Ob aspektah svjaznosti v tekste kak celom [On aspects of text connectivity as a whole]. Sintaksisteksta [Textsyntax ] / otv. red. G.A. Zolotova. M.: Nauka, 1979.pp.49-67.

Kol'cova L.N., 2010. Vnutrennij veb-portal [Internal web portal]. Sekretar'-referent [Secretary assistant]. № 10. pp.18-25.

Morozova O.N., 2011. Politicheskaja internetkommunikacija: eerol', funkcii i formy [Political Internet communication: its role, functions and forms]. Politicheskajalingvistika [Political linguistics]. 2011. no. 1. pp. 156-161.

Smirnov F.O., 2004. Nacional'no-kul'turnye osobennostij elektronnoj kommunikacii na anglijskom i russkom jazykah: dis. ... kand. filol. nauk [National-cultural features of electronic communication in English and Russian Cand. philol. sci. diss.]. Jaroslavl'. 220 p.

Sokolov V.S., 2005. Dokumentacionnoe obespechenie upravlenija [Management Documentation]. M.: Forum-Infra-M.233 p.

Ul'janova M.A., 2014. Klassifikacija zhanrov internetdiskursa [Classification of Internet Discourse Genres]. Lingua mobilis. 2014. no. 3. pp.102-110.

Usacheva O.Ju., 2010. K opredeleniju ponjatija «zhanrinterneta» i postroenijumodeli zhanra v srede internet [To the definition of the concept of "Internet genre" and the construction of a model of the genre in the Internet]. Mir russkogoslova [World of Russian word]. 2010. no. 1.pp. 51-57.

Shevchenko I.S., 2007.Teorija Jurgena Habermasa i kriticheskij analiz diskursa [Jürgen Habermas Theory and Critical Discourse Analysis]. Vestnik
HNU im. V.N. Karazina [Herald of HNU of V.N. Karazin]. 2007. no. 773.pp. 12-15

ShhipicinaL.Ju., 2009. Zhanry komp'juternooposredovannoj kommunikacii : monografija [Genres of computer-mediated communication: a monograph]. Pomorskijgos. un-t im. M.V. Lomonosova [Pomorsk State University of M.V. Lomonosov]. Arhangel'sk : Pomor. un-t. 38 p. Crystal D., 2004.The Language Revolution. Cambridge : Polity Press, 2004. 128 p.

Herring S., 1996. Two Variants of an Electronic Message Schema. Computer-Mediated Communication: Linguistic, Social and Cross-Cultural Perspectives. Amsterdam: Routledge, 1996. pp. 13-28.

Thurlow C., 2001. The Internet and Language. Concise Encyclopedia of Sociolinguistics. Elsaivier, 2001. p. $105-125$.

\section{SOURCES}

Intranet: osnovnye zadachi i effektivnye reshenija [Intranet: Key Tasks and Effective Solutions]. URL: https://inside-pr.ru/zhurnal/portaly-i-seti/intranetportal/item/396-intranet-osnovnye-zadachi-ieffektivnye-resheniya (data obrashcheniya: 25.08.2019).

Intranet [Intranet]. Slovar'IT: Internet [IT Dictionary: Internet]. URL: http://edumarket.ru/glossary/ internet/3301/ (data obrashcheniya: 30.08.2019).

Selektornoesoveshhaniepostolknovenijupoezdov [Train collision conference call]. URL: https:// www.m24.ru/videos/dtp/20052014/51167 (data obrashcheniya: 20.08.2019).

Hvatit boltat': pochemu kompanii zapreshhajut soveshhanija [Stop talking: why companies ban meetings]. URL: https://www.rbc.ru/own_business/ 17/01/2018/5a5c76e19a79472b3d4128b0 (data obrashcheniya: 25.08.2019).

RamblerGroup. URL: https://ramblergroup.com/ assets/media/afishadaily (data obrashcheniya: 23.08.2019). 
О.А. Евтушенко, С.В. Первухина. Электронный модус современного административного дискурса

\section{Information About the Authors}

Oksana A. Evtushenko, Doctor of Sciences (Philology), Professor, Department of Foreign Languages, Volgograd State Technical University, Prosp. Lenina, 28, 400066 Volgograd, Russia, ksenja22@yahoo.com, https://orcid.org/0000-0001-6280-4731

Svetlana V. Pervukhina, Doctor of Sciences (Philology), Professor, Department of World Languages and Cultures, Don State Technical University, Gagarina Sq., 1, 344000 Rostov-on-Don, Russia, s_pervuhina@mail.ru, https://orcid.org/0000-0001-5475-8384

\section{Информация об авторах}

Оксана Александровна Евтушенко, доктор филологических наук, профессор кафедры иностранных языков, Волгоградский государственный технический университет, просп. Ленина, 28, 400066 г. Волгоград, Россия, ksenja22@yahoo.com, https://orcid.org/0000-0001-6280-4731

Светлана Владимировна Первухина, доктор филологических наук, профессор кафедры мировых языков и культур, Донской государственный технический университет, пл. Гагарина, 1 , 344000 г. Ростов-на-Дону, Россия, s_pervuhina@mail.ru, https://orcid.org/0000-0001-5475-8384 